\title{
Characterization of Humic Acids from Raised Bog Peat
}

\author{
Maris Klavins ${ }^{1}$, Oskars Purmalis ${ }^{2}{ }^{1,2}$ University of Latvia
}

\begin{abstract}
Humic substances form most of the organic component of soil, peat and natural waters, but their structure and properties very much differs depending on their source. The aim of this study is to characterize humic acids from raised bog peat to evaluate the homogeneity of humic acids isolated from the bog bodies and study peat humification impact on properties of humic acids. Peat humic acids (HA) have an intermediate position between the living organic matter and coal organic matter.
\end{abstract}

Keywords: Humic substances; composition; soil; peat; Latvia.

\section{INTRODUCTION}

Humic substances (HS) are the most widely found organic substances on the Earth. Humic substances are a general category of naturally occurring, biogenic, heterogeneous organic substances that can generally be characterised as being yellow to black in colour, of high molecular weight and refractory. Humic substances can be divided in three fractions: a) humin is the fraction of humic substances that is not soluble in water at any $\mathrm{pH} ; \mathrm{b}$ ) humic acid (HA) is the fraction of humic substances that is not soluble in water under acidic conditions (below $\mathrm{pH} 2$ ), but becomes soluble at greater $\mathrm{pH}$; c) fulvic acid (FA) is the fraction of humic substances that is soluble under all $\mathrm{pH}$ conditions [1]. Humic substances form most of the organic component of soil, peat and natural waters, they influence the process of formation of fossil fuels, and play a major role in the global carbon geochemical cycle [1]. In the same time humic substances (at first humic acids) may be regarded as a valuable substance which may found manifold uses for different purposes [2] and their industrial production and application is growing [3, 4]. Thus humic substances are of great importance not only considering processes in environment, but also as an important resource and there is an increasing interest into studies of properties of humic acids.

In the studies of humic substances still actual is the question about dependence of their properties depending on origin. It has been shown, that the structure and properties of humic substances differ for humic acids of different $[5,6]$, but in the same time, considering the great variability in natural organic matter properties, the actual relationship is far from being explained. Another open question can be related to the genesis of peat and fossil carbon deposits and development of peat. Character of transformation of living organic matter is very complex object of study, considering the high variability of the environmental conditions under which the living organic matter is decaying, slow pace of the humification reactions and the large number and structural differences in organic molecules composing living organic matter. It can be supposed that the humification conditions may have impact on structure and properties of refractory intermediate transformation products of living organic matter - humic substances. From this perspective it is important to study humification processes in the conditions where the transformation of living organic matter could be studied in relatively homogeneous and stable environment - in the bogs.

Peat is a light brown to black organic material formed under waterlogged conditions from the partial decomposition of mosses and other bryophytes, sedges, grasses, shrubs, or trees [7]. The interest about peat properties is growing as far as peat as substance supports and influences bog and wetland ecosystems, but peat profiles can serve as an archive indicating conditions in past environments $[8,9]$. In form of peat is stored significant amounts of organic carbon and thus peat reserves play major role in the carbon biogeochemical cycling and is of especial role considering the ongoing climate change process $[10,11]$. Industrial and agricultural uses of peat are growing $[3,4]$ and significant amounts of peat are mined industrially. Considering this, there is an increasing interest into studies of peat properties diagenesis of their properties. The humification in the peat take place in very much differing conditions both at spatial scale, both under temporally changing conditions (historically peat development can last for many thousands years). During peat development even at one special site major changes in vegetation, temperature, amount of precipitations and correspondingly of the bog hydrological conditions, land use changes in the basin of wetland can take place $[9,12,13]$, thus it might be expected to find corresponding changes in properties of peat humic substances, identifying molecular descriptors of organic matter diagenesis process. However relations between peat properties (especially in full peat profiles) and properties of peat humic substances have been an object of very few studies [14-16].

The aim of this study is to characterize humic acids from raised bog peat samples through appropriate chemical and spectroscopic techniques: elemental and functional analysis, UV, fluorescence spectroscopy, FTIR, ESR, ${ }^{1} \mathrm{H}$ NMR, ${ }^{13} \mathrm{C}$ NMR as well as degradation studies (pyrolysis-gas chromatography/mass spectrometry Py GC/MS) to evaluate the homogeneity of humic acids isolated from the bog bodies and study peat humification impact on properties and structure of humic acids.

\section{MATERIALS AND METHODS}

\section{Materials}

Analytical quality reagents (Merck Co., Sigma - Aldrich Co., Fluka Chemie AG) were used without purification. For preparation of solutions, high purity water Millipore Elix 3 (Millipore Co.) $10-15 \mathrm{M} \Omega \mathrm{cm}$ was used throughout the study.

\section{Peat sampling and characterization}

Peat profiles were obtained from well-characterized, typical raised bogs [17, 18] - Eipurs, Dizpurvs and Dzelve. Studied 
bogs are located in lowlands, they are of similar origin (they have developed due to ground paludification), although their lithology is largely differing. Full peat profile were obtained and cut into layers (Table 1). Peat samples were dried at $105^{\circ} \mathrm{C}$, and then homogenized and sieved through a 1-mm sieve. The analysis of botanical composition was performed microscopically, using a Carl-Zeiss binocular microscope and decomposition degree was determined [19]. Humic and fulvic acid ratio (HA/FA) was determined as suggested by Tan [20], but humification degree by Borgmark [21]. The ${ }^{14} \mathrm{C}$ dating of peat samples was done at the Institute of Geology of the Tallinn Technical University (Estonia). Carbon, hydrogen, nitrogen and sulphur concentrations in the peat and humic acid samples were determined by combustion-gas chromatography technique, using an Elemental Analyzer Model EA-1108 (Carlo Erba Instruments). Ash content was measured after heating $50 \mathrm{mg}$ of each peat sample at $750{ }^{\circ} \mathrm{C}$ for $8 \mathrm{~h}$. Elemental composition was corrected considering the ash content, and the oxygen amount was calculated as a difference.

\section{Isolation of humic acids}

Humic acids were extracted from peat and purified as suggested previously [20, 22]. Briefly, $100 \mathrm{~g}$ of air dry peat was reacted with $2 \mathrm{~L}$ of $0.1 \mathrm{M} \mathrm{HCl}$ for $1 \mathrm{~h}$. The slurry was allowed to settle and the aqueous phase was decanted and discarded. Approximately $1 \mathrm{~L}$ of $\mathrm{H}_{2} \mathrm{O}$ was added to the peat mass and the resulting slurry was allowed to incubate for $30 \mathrm{~min}$, after which the $\mathrm{pH}$ of the slurry was adjusted to 7 with the addition of $1 \mathrm{M} \mathrm{NaOH}$. This was followed by the addition of a sufficient quantity of $1 \mathrm{M} \mathrm{NaOH}$ (done under $\mathrm{N}_{2}$ ), to bring the total volume of the solution phase to $2 \mathrm{~L}$ and the resulting slurry was stirred under $\mathrm{N}_{2}$ gas. After $24 \mathrm{~h}$ the alkaline slurry was filtered through glasswool and the particle free filtrate was acidified to a $\mathrm{pH} 1$, with the addition of $6 \mathrm{M}$ $\mathrm{HCl}$. This solution was then allowed to settle then it was centrifuged and the supernatant was discarded. The sediment (which contained humic acid) was washed with distilled water and repeatedly centrifuged discarding the supernatant. Solid residue after centrifugation was then suspended in a mixture of $0.1 \mathrm{M} \mathrm{HCl}$ and $0.3 \mathrm{M} \mathrm{HF}$, to remove mineral particles. This treatment was repeated until the ash content was reduced less than $2 \%$. Afterwards humic acid dispersion in distilled water were dialyzed against water to remove chlorides and resulting humic acids were lyophilized.

\section{Characterization of humic acids}

Elemental composition. Carbon, hydrogen, nitrogen and sulphur concentrations in the peat and humic acid samples (elemental analysis of $\mathrm{C}, \mathrm{H}, \mathrm{N}, \mathrm{S}$ ) were determined by combustion-gas chromatography technique, using an Elemental Analyzer Model EA-1108 (Carlo Erba Instruments). Ash content was measured after heating $50 \mathrm{mg}$ of each peat sample at $750{ }^{\circ} \mathrm{C}$ for $8 \mathrm{~h}$. Elemental composition was corrected considering the ash content, and the oxygen amount was calculated as a difference. The Van Krevelen graphical-statistical method was applied as used for the study of the structure on the basis of elemental analysis data [6].
Carboxylic groups and total acidity. An automatic titrator TitroLine easy (Schott-Geräte $\mathrm{GmbH}$ ) was used for measuring carboxylic and phenolic acidity of each HA. The known Caacetate method [20], based on the formation of acetic acid, was used for determining the total number of carboxylic groups. HAs (20 mg) were weighed into a $100 \mathrm{ml}$ Erlenmeyer flask and under $\mathrm{N}_{2} 10 \mathrm{ml}$ of the $0.2 \mathrm{M}$ calcium acetate solution were added. Samples were potentiometrically titrated to $\mathrm{pH}$ 9.0 with $0.1 \mathrm{M} \mathrm{NaOH}$. To estimate the total acidity, $20 \mathrm{mg}$ of humic acid, were dispersed in $10 \mathrm{ml} 0.1 \mathrm{M} \mathrm{Ba}(\mathrm{OH})_{2}$ solution, which was then shaken overnight under $\mathrm{N}_{2}$ atmosphere, filtered and washed with water. The filtrate, together with the washing solution, was potentiometrically titrated with $0.1 \mathrm{M}$ $\mathrm{HCl}$ down to $\mathrm{pH} 8.4$ under $\mathrm{N}_{2}$ flow.

Colloidal stability test. In coagulation tests [23], $0.2 \mathrm{~g} / \mathrm{L}$ of HA were used, increasing the amounts of coagulation electrolyte $(\mathrm{NaCl}$, up to $1 \mathrm{~mol} / \mathrm{L})$ at constant $\mathrm{pH}$ 3. Samples were left for 3 days. The coagulation intensity were determined with a HACH DR/2000 spectrophotometer, measuring turbidity at $450 \mathrm{~nm}$. The coagulation ratio were calculated using the equation (1):

$$
T=\frac{T_{0.0001}-T_{1}}{T_{0.01}-T_{1}},
$$

where $\mathrm{T}$ stands for turbidity and the concentration of coagulation electrolyte is $0.0001-1 \mathrm{~mol} / \mathrm{l}$.

Hydrophobicity of humic substances. Hydrophobicity of humic substances was characterized by their distribution between the water and polyethylene (PEG) glycol phases (PEG 20000, Fluka) [24] as the distribution coefficient $\mathrm{K}_{\mathrm{PEG} / \mathrm{W}}$ (analogous to the octanol/water distribution coefficient $\mathrm{K}_{\mathrm{ow}}$ ).

UV-Vis spectral ratios. UV-Vis spectra were recorded on a Thermospectronic Helios $\gamma$ UV (Thermoelectron Co) spectrophotometer in a $1-\mathrm{cm}$ quartz cuvette. The UV-Vis spectral ratios $E_{2} / E_{3}$ and $E_{4} / E_{6}$ [25], i.e. the ratio of absorbance at 280 and 360, and 465 and $665 \mathrm{~nm}$ respectively, was determined for $10 \mathrm{mg}$ of humic acid solutions in $1000 \mathrm{ml}$ of $0.05 \mathrm{M} \mathrm{NaOH}$. Absorbance at $465 \mathrm{~nm}$ characterises presence of humic substances formed after initial stages of living matter decay, but absorbance at $665 \mathrm{~nm}$ indicate presence of well humified organic matter.

\section{RESULTS AND DISCUSSION}

For the isolation of humic acids peat from 3 representative bogs were studied, covering major lithological classes of raised bog peat (Table 1.). Upper peat layers are common for raised bog, but lower layers of peat profiles represent fen peat. Peat decomposition degree changes from $10 \%$ till $60 \%$, but the age of the studied layers from $<100{ }^{14} \mathrm{C}$ years till $9000{ }^{14} \mathrm{C}$ years. If in upper peat layers humification degree is lower and correspondingly HA/FA ratio is $<10$, then in more decomposed peat this ration is $>30$, respectively peat humic matter is dominated by humic acids, later selected as a major object of studies.

Basic peat properties can be analysed using peat elemental (C, H, N, O, S) composition (Table 2). The ash content in the 
studied bogs range between $1.11 \%$ until $>6 \%$. The $\mathrm{C}$ concentration range from $\sim 40$ to $55 \%$ and $\mathrm{H}$ from 5.4 to $6.2 \%, \mathrm{~N}$ from 0.5 to $>2 \%, \mathrm{~S}$ from 0.3 to $1.2 \%$. The elemental composition of peat in the Eipurs Bog is comparatively variable and reflects the changes in the peat decomposition degree and peat type. $\mathrm{C}$ concentration in the peat is increasing starting from the upper layers up to level of $53 \%$. Changes of $\mathrm{N}$ concentrations (increased in the upper and lower horizons of the bog, but also demonstrating increased values coinciding with the changes in the peat composition and formation conditions) could be associated with changes in the peat botanical composition and decomposition degree. S concentrations are significantly lower just in upper layer of the peat bog, but comparatively stable along the peat column. At the same time the elemental composition of Dzelves Bog is very much different and largely reflects the peat column composition: the $\mathrm{C}$ content in the upper layers is much lower $(\sim 45 \%)$ and comparatively uniform up to depth of $3.25 \mathrm{~m}$, but then rapidly increases reaching $55 \%$ for highly decomposed peat. The same trends of changes reflect elemental ratios $(\mathrm{O} / \mathrm{C}, \mathrm{H} / \mathrm{C}, \mathrm{N} / \mathrm{C})$.

There was significant variation in elemental composition of HAs within the peat profiles. Depending on the bog and the intervals of changes, the elemental compositions of the studied peat HAs were highly variable: $\mathrm{C}$ was $49-57 \%$; $\mathrm{H}$ was $4.6-$ $5.7 \%, \mathrm{~N}$ was $1.6-2.8 \%, \mathrm{~S}$ was $0.5-1.5 \%$ and ash was $0.1-$ $1.2 \%$. The $\mathrm{O}$ content, with range $32-42 \%$, was determined by mass balance. In general, $\mathrm{C}$ and $\mathrm{H}$ concentrations increased with depth. $\mathrm{N}$ concentrations decreased with depth, but $\mathrm{S}$ concentration was very variable down the profile. The elemental composition of HAs from peat in Latvia is of similar magnitude to those for peat HAs from other regions of the world [14, 16, 22, 26, 27]. The peat HAs were analyzed using van Krevelen graphs as frequently applied for studies of $\mathrm{HA}$ and the $\mathrm{C}$ biogeochemical cycle. According to Orlov [28], the index of atomic ratios $\mathrm{O} / \mathrm{C}, \mathrm{H} / \mathrm{C}$ and $\mathrm{N} / \mathrm{C}$ is useful in identification of structural changes and the degree of maturity of HSs obtained from different environments. The relation between $\mathrm{H} / \mathrm{C}$ atomic ratio and $\mathrm{O} / \mathrm{C}$ atomic ratio of HAs of differing decomposition degree - beginning with bog plants up to brown coal, lignite and coal - reveals changes in the associated elemental composition (Fig. 1). Figure 1 could be considered a graphical representation of the humification process, indicating the degree of maturity and intensity of degradation processes such as dehydrogenation (reduction of $\mathrm{H} / \mathrm{C}$ ratio), decarboxylation (reduction of $\mathrm{O} / \mathrm{C}$ ratio), demethylation occurring during the decay of peat-forming plants, and peat humus maturation continuing up to coal.

These changes are especially evident if atomic ratios of peat-forming plants (Sector 3 in Fig. 1) are compared to the atomic ratio of organic matter of a high decomposition degree (low moor peat, coal) (Sector 3 in Fig. 1). From the point of view of chemistry, peat HAs have an intermediate position (Sector 5 in Fig. 1) between the living organic matter and coal organic matter and their structure is formed in a process in which more labile structures (carbohydrates, amino acids, etc.) are destroyed, but thermodynamically more stable aromatic and polyaromatic structures emerge.

1. TABLE

PROPERTIES OF PEAT USED FOR EXTRACTION OF HUMIC ACIDS

\begin{tabular}{|c|c|c|c|c|c|c|c|}
\hline Bog & $\begin{array}{l}\text { Peat location } \\
\text { depth from } \\
\text { surface, } \mathrm{cm}\end{array}$ & $\begin{array}{c}\text { Peat } \\
\text { decomposition } \\
\text { degree, } \%\end{array}$ & $\begin{array}{l}\text { Peat age, } \\
{ }^{14} \mathrm{C} \text { years }\end{array}$ & $\begin{array}{l}\text { Peat botanical } \\
\text { composition }\end{array}$ & Peat type & $\begin{array}{l}\text { Humification } \\
\text { degree }\end{array}$ & $\mathrm{HA} / \mathrm{FA}$ \\
\hline \multirow[t]{5}{*}{ Eipurs } & $0-25$ & 10 & 70 & Sphagnum fuscum & Raised & 0.49 & 5.95 \\
\hline & $135-170$ & 30 & 1300 & $\begin{array}{l}\text { Cotton grass- } \\
\text { sphagnum }\end{array}$ & Raised & 0.84 & 25.53 \\
\hline & $230-240$ & 23 & 2660 & Sphagnum fuscum & Raised & 0.67 & 16.01 \\
\hline & $320-358$ & 41 & 6830 & Pine, wood & $\begin{array}{l}\text { Raised - } \\
\text { transitional }\end{array}$ & 1.29 & 33.49 \\
\hline & $410-456$ & 27 & 8800 & Hypnum, sedge & Fen & 1.27 & 38.52 \\
\hline \multirow[t]{4}{*}{ Dzelve } & $30-40$ & 12 & 75 & Sphagnum fuscum & Raised & 0.48 & 10.27 \\
\hline & $190-200$ & 10 & 1940 & Sphagnum fuscum & Raised & 0.38 & 6.80 \\
\hline & $310-320$ & 12 & 2230 & Sphagnum fuscum & Raised & 0.74 & 8.13 \\
\hline & $340-350$ & $>60$ & 4810 & Cotton-grass & Raised & 2.99 & 71.76 \\
\hline \multirow[t]{3}{*}{ Dizpurvs } & $0-20$ & 13 & 50 & $\begin{array}{c}\text { Sphagnum }- \text { cotton } \\
\text { grass }\end{array}$ & Raised & 0.45 & 6.75 \\
\hline & $240-260$ & 37 & 2300 & Sedge - pinus & Fen & 0.65 & 8.43 \\
\hline & $400-430$ & 40 & 5740 & Sedge - hypnum & Fen & 1.32 & 24.55 \\
\hline
\end{tabular}


2. TABLE

PEAT ELEMENTAL COMPOSITION

\begin{tabular}{|c|c|c|c|c|c|c|c|c|c|}
\hline Bog & $\begin{array}{c}\text { Peat location depth } \\
\text { from surface, cm }\end{array}$ & $\mathrm{C}$ & $\mathrm{H}$ & $\mathrm{N}$ & $\mathrm{S}$ & $\mathrm{Ash}$ & $\mathrm{O} / \mathrm{C}$ & $\mathrm{H} / \mathrm{C}$ & $\mathrm{N} / \mathrm{C}$ \\
\hline Eipurs & $0-25$ & 41.97 & 5.69 & 0.59 & 0.37 & 3.61 & 0.85 & 1.61 & 0.012 \\
\hline & $135-170$ & 48.20 & 5.91 & 0.66 & 0.88 & 1.18 & 0.53 & 1.49 & 0.013 \\
\hline & $230-240$ & 49.21 & 5.68 & 0.82 & 0.69 & 1.11 & 0.65 & 1.38 & 0.014 \\
\hline & $320-358$ & 49.15 & 5.49 & 2.00 & 0.88 & 4.89 & 0.62 & 1.29 & 0.035 \\
\hline & $410-456$ & 52.92 & 5.28 & 2.13 & 0.98 & 6.01 & 0.55 & 1.19 & 0.034 \\
\hline Dzelve & $30-40$ & & & & & & & & \\
& & 44.77 & 5.91 & 0.73 & 0.89 & 1.18 & 0.80 & 1.58 & 0.014 \\
\hline & $190-200$ & 45.53 & 5.60 & 0.47 & 0.81 & 1.29 & 0.78 & 1.47 & 0.009 \\
\hline & $310-320$ & 45.73 & 5.55 & 0.62 & 1.22 & 3.76 & 0.77 & 1.45 & 0.012 \\
\hline & $340-350$ & 55.53 & 6.20 & 1.23 & 1.19 & 5.82 & 0.48 & 1.34 & 0.019 \\
\hline Dizpurvs & $0-20$ & 42.36 & 5.32 & 0.67 & 0.43 & 1.21 & 0.79 & 1.49 & 0.012 \\
& & & & & & & & & \\
\hline & $240-260$ & 46.58 & 5.89 & 0.83 & 0.56 & 2.05 & 0.65 & 1.42 & 0.010 \\
\hline & $400-430$ & 49.12 & 5.97 & 1.16 & 0.81 & 2.37 & 0.82 & 1.35 & 0.012 \\
\hline
\end{tabular}

3. TABLE

ELEMENTAL COMPOSITION OF PEAT HUMIC ACIDS

\begin{tabular}{|l|l|l|l|l|l|l|l|}
\hline \multicolumn{1}{|c|}{ Humic acid } & $\mathrm{C}, \%$ & $\mathrm{H}, \%$ & $\mathrm{~N}, \%$ & $\mathrm{~S}, \%$ & $\mathrm{O} / \mathrm{C}$ & $\mathrm{H} / \mathrm{C}$ & $\mathrm{N} / \mathrm{C}$ \\
\hline Eipurs HA $0.0-0.25$ & 52.40 & 5.39 & 2.43 & 1.50 & 0.550 & 1.23 & 0.04 \\
\hline Eipurs HA 1.35 - 1.70 & 53.20 & 4.80 & 2.13 & 1.05 & 0.547 & 1.07 & 0.03 \\
\hline Eipurs HA 2.30 - 2.40 & 54.70 & 5.04 & 1.87 & 0.87 & 0.514 & 1.10 & 0.03 \\
\hline Eipurs HA 3.20 - 3.58 & 52.70 & 4.34 & 2.25 & 0.83 & 0.567 & 0.98 & 0.04 \\
\hline Eipurs HA 4.10 - 4.56 & 55.30 & 4.49 & 2.48 & 1.01 & 0.498 & 0.97 & 0.04 \\
\hline Dzelve HA 0.30 - 0.40 & 52.25 & 4.51 & 2.59 & 0.77 & 0.573 & 1.03 & 0.04 \\
\hline Dzelve HA 1.90 - 2.00 & 56.17 & 5.11 & 2.29 & 0.84 & 0.476 & 1.08 & 0.03 \\
\hline Dzelve HA 3.10 - 3.20 & 57.05 & 5.16 & 2.66 & 0.80 & 0.452 & 1.08 & 0.04 \\
\hline Dzelve HA 3.40 - 3.50 & 59.49 & 3.98 & 2.02 & 0.68 & 0.427 & 0.80 & 0.03 \\
\hline Dizpurvs HA 0.0 - 0.20 & 56.54 & 5.71 & 3.24 & 0.88 & 0.446 & 1.20 & 0.05 \\
\hline Dizpurvs HA 2.40 - 2.60 & 56.05 & 4.35 & 2.14 & 0.89 & 0.490 & 0.93 & 0.03 \\
\hline Dizpurvs HA 4.00 - 4.30 & 58.11 & 4.78 & 3.10 & 0.90 & 0.428 & 0.98 & 0.05 \\
\hline
\end{tabular}

4. TABLE

FUNCTIONAL PROPERTIES OF PEAT HUMIC ACIDS

\begin{tabular}{|l|c|c|c|c|c|c|c|}
\hline \multicolumn{1}{|c|}{ Humic acid } & $\begin{array}{c}-\mathrm{COOH}, \\
\mathrm{mmol} \mathrm{g}\end{array}$ & $\begin{array}{c}\text { Total acidity, } \\
\mathrm{mEq} \mathrm{g}\end{array}$ & $\begin{array}{c}\mathrm{ArOH}, \mathrm{mmol} \\
\mathrm{g}\end{array}$ & $\mathrm{K}_{\mathrm{PEG} / \mathrm{W}}$ & $\mathrm{E}_{4} / \mathrm{E}_{6}$ & $\mathrm{E}_{2} / \mathrm{E}_{3}$ & $\begin{array}{c}\text { Coagulation } \\
\text { ratio T }\end{array}$ \\
\hline Eipurs HA 0.0 - 0.25 & 2.70 & 8.50 & 5.80 & 1.66 & 5.00 & 3.4 & 0.968 \\
\hline Eipurs HA 1.35 - 1.70 & 4.70 & 7.71 & 3.01 & 11.80 & 6.23 & 2.84 & 1.035 \\
\hline Eipurs HA 2.30 - 2.40 & 4.60 & 6.13 & 1.53 & 10.82 & 6.40 & 2.92 & 1.010 \\
\hline Eipurs HA 3.20 - 3.58 & 6.20 & 6.40 & 0.20 & 8.19 & 8.00 & 3.09 & 1.019 \\
\hline Eipurs HA 4.10 - 4.56 & 4.70 & 7.60 & 2.90 & 9.86 & 6.55 & 3.08 & 1.023 \\
\hline Dzelve HA 0.30 - 0.40 & 4.60 & 8.16 & 3.56 & 8.63 & 10.00 & 3.39 & 0.972 \\
\hline Dzelve HA 1.90 - 2.00 & 4.20 & 9.31 & 5.11 & 10.60 & 9.00 & 3.31 & 1.000 \\
\hline Dzelve HA 3.10 - 3.20 & 4.40 & 8.41 & 4.01 & 17.60 & 3.43 & 2.94 & 1.016 \\
\hline Dzelve HA 3.40 - 3.50 & 5.40 & 6.70 & 1.30 & 6.70 & 5.75 & 2.97 & 1.037 \\
\hline Dizpurvs HA 0.0 - 0.20 & 3.60 & 7.00 & 3.40 & 6.18 & 3.00 & 3.26 & 0.940 \\
\hline Dizpurvs HA 2.40 - 2.60 & 5.20 & 8.10 & 2.90 & 16.10 & 3.25 & 2.63 & 0.950 \\
\hline Dizpurvs HA 4.00 - 4.30 & 5.00 & 7.50 & 2.50 & 8.06 & 3.12 & 2.77 & 1.147 \\
\hline
\end{tabular}


Comparatively, the studied peat HAs are at the start of the transformation process of living organic matter.

The dominant functional groups in the structure of peat humic acids are carboxyl and phenolic hydroxyl groups. In humic substances from peat, concentrations of carboxyl groups and phenolic hydroxyl groups are lower (Table 1), than in humic substances from other sources (waters, soils, sediments) $[2,5,6,29]$.

Concentrations of carboxyl and phenolic hydroxyl groups changes depending on the depth of peat from which humic acids have been isolated: in upper layers concentration of carboxylgroups is lower for all three studied bogs and total acidity is determined by presence of phenolic hydroxyl groups. Pattern of changes of concentration of carboxylgroups demonstrates that carboxylic acidity is increasing with depth of peat location and the humification degree. In general, the concentrations of carboxyl groups correlate to the $\mathrm{O} / \mathrm{C}$ ratio, thus indicating that the dominant portion of the oxygen in humic molecules is in form of carboxyl groups. An important characteristic of humic acids is their ability to coagulate in acidic environment or due to changes of ionic strength. We have studied the changes in the ability of humic acids to coagulate in the presence of increasing concentrations of dissolved salt (coagulation test), and have found that peat humic acid coagulation ability increases with depth of humic acid within a peat profile (Table 4$)$.

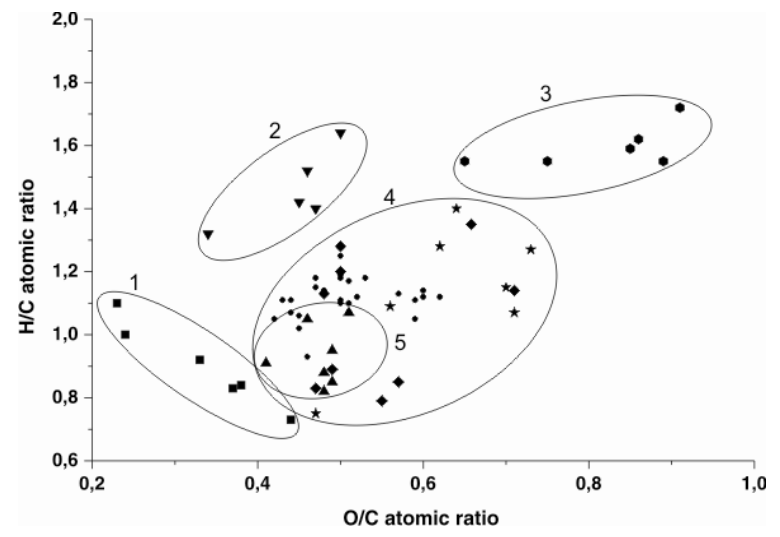

Fig. 1. Van Krevelen (H/C vs. O/C atomic ratio) graph of bog plants ( ); HAs isolated from peat samples from bogs in Latvia $(\bullet)$; reference peat HA and peat HA $(\star)$; soil HA $(\diamond)$; HA from different coals and lignite $(\boldsymbol{\square})$, sedimentary HA $(\boldsymbol{\nabla})$ and aquatic HA $(\boldsymbol{\Delta})$.

Important information about basic structural differences of humic substances can provide their UV spectra. The UV-Vis spectra of peat HA examined are featureless, and they monotonically decreases with increasing wavelength. The ultraviolet spectra of humic acids from different peat layers are similar, differing only slightly in optical density. The slope of the adsorption curves as measured by the ratios of UV absorbancy (Table 4) at 280 and $360\left(\mathrm{E}_{2} / \mathrm{E}_{3}\right)$ and 465 and $665 \mathrm{~nm},\left(\mathrm{E}_{4} / \mathrm{E}_{6}\right)$ have been suggested to be related to the condensation of aromatic groups (aromaticity), and also to particle size and molecular weight [30]. Higher $\mathrm{E}_{4} / \mathrm{E}_{6}$ ratios measured for humic acids from deeper bog layers accordingly to data in the literature suggest a lower degree of condensed aromatic systems and smaller particle sizes or molecular weights.

\section{CONCLUSIONS}

Peat humic acids (HA) have an intermediate position between the living organic matter and coal organic matter and their structure is formed in a process in which more labile structures (carbohydrates, amino acids, etc.) are destroyed, but thermodynamically more stable aromatic and polyaromatic structures emerge. Comparatively, the studied peat HAs are at the start of the transformation process of living organic matter. Concentrations of carboxyl and phenolic hydroxyl groups changes depending on the depth of peat from which HAs have been isolated: and carboxylic acidity is increasing with depth of peat location and the humification degree.

\section{REFERENCES}

[1] Stevenson, F.J. Humus chemistry: Genesis, composition, reactions. $2^{\text {nd }}$ ed. New York: Wiley, 1994.

[2] Klavins, M. Aquatic humic substances. Riga: University of Latvia, 1998.

[3] Brown, P.A., Gill S.A., Allen, S.J. Metal removal from wastewater using peat. Water Resources, 34, 2000. 3907-3916.

[4] Ghaly, R. A., Pyke, J. B., Ghaly, A. E., Ugursal, V. I. Remediation of Diesel-Oil-Contaminated Soil Using Peat, Energy Sources, A: Recovery, Utilization, and Environmental Effects. Chemosphere, 21, 1999. p. $785-$ 799.

[5] Remaury, M., Benmouffok, A., Dagnac, J., Gauquelin, T. Pedogenesis and distribution of humic substances in Pyrenean soils. France. Analusis, $\quad 27, \quad 1999 . \quad$ p. 402-404. http://dx.doi.org/10.1051/analusis:1999270402

[6] Barančikova, G., Senesi, N., Brunetti, G. Chemical and spectroscopic characterization of humic acids isolated from different Slovak soil types. Geoderma 78. 1997. p. 251-266. http://dx.doi.org/10.1016/S00167061(97)00033-5

[7] Cocozza, C. D’Orazio, V., Miano, T.M., Shotyk, W. Characterization of solid and aqueous phases of a peat bog profile using molecular fluorescence spectroscopy, ESR and FT-IR, and comparison with physical properties. Organic Geochemistry, 34, 2003. p. 49-60. http://dx.doi.org/10.1016/S0146-6380(02)00208-5

[8] Yeloff, D., Mauquoy, D. The influence of vegetation composition on peat humification: implications for paleoclimatic studies. Boreas, 35, 2006. p. 662-673. http://dx.doi.org/10.1111/j.1502-3885.2006.tb01172.x

[9] Zaccone, C., Miano, T.M., Shotyk, W. Qualitative comparison between raw peat and related humic acids in an ombrotrophic bog profile. Organic Geochemistry, 38, 2007. p. 151-160. http://dx.doi.org/10.1016/j.orggeochem.2006.06.023

[10] Borgmark, A. Holocene climate variability and periodicities in southcentral Sweden, as interpreted from peat humification analysis. Holocene, 15(3), 2005. 2 p. 387-395. http://dx.doi.org/10.1191/0959683605hl816rp

[11] Falkowski, P., Scholes, R. J., Boyle, E., Canadell, J., Canfield, D., Elser, J., Gruber, N., Hibbard, K., Hogberg, P., Linder, S., Mackenzie, F.T., Moore, B. Pedersen, T., Rosenthal, Y., Tan, K.H. Humic matter in soil and the environment: Principles and Controversies. New York: Marcel Dekker, 2003.

[12] Caseldine, C.J. Baker, A., Charman D.J., Hendon, D. A. Comparative study of optical properties of $\mathrm{NaOH}$ peat extracts: implications for humification studies. Holocene, 10, 2000. p. 649-658. http://dx.doi.org/10.1191/095968300672976760

[13] Chapman, S.J., Campbell, C.D., Fraser, A.R. Puri, G. FTIR spectroscopy of peat in and bordering Scots pine woodland: relationship with chemical and biological properties. Soil Biology and Biochemistry, 33, 2001. p. 1193-1200. http://dx.doi.org/10.1016/S00380717(01)00023-2

[14] Anderson, H., Hepburn, A. Variation of humic substances within peat profile, In: Peat and water (Ed. C.H. Fuchsman). New York: Academic Press, 1986. p. 177-194.

[15] Zaccone, C., Cocozza, C., Cheburkin, A.K., Shotyk, W., Miano, T.M. Enrichment and depletion of major and trace elements, and radionuclides in ombrotrophic raw peat and corresponding humic acids. Geoderma,

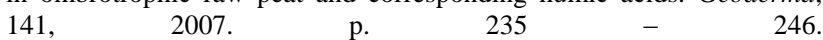
http://dx.doi.org/10.1016/j.geoderma.2007.06.007 
[16] Zaccone, C., Cocozza, C., Cheburkin, A.K., Shotyk, W., Miano, T.M. Distribution of $\mathrm{As}, \mathrm{Cr}, \mathrm{Ni}, \mathrm{Rb}, \mathrm{Ti}$ and $\mathrm{Zr}$ between peat and its humic fraction along an undisturbed ombrotrophic bog profile (NW Switzerland). Applied Geochemistry, 23, 2008. p. $25-33$. http://dx.doi.org/10.1016/j.apgeochem.2007.09.002

[17] Silamikele, I., Nikodemus, O., Kalnina, L., Purmalis, O., Sire, J., Klavins, M. Properties of peat in ombrotrophic bogs depending on the humification process. In: Mires and Peat (Eds. M. Klavins). Riga: University of Latvia Press, 2010. p. 71-95.

[18] Kuske, E., Silamikele, I., Kalnina, L., Klavins, M. Peat formation conditions and peat properties: a study of two ombrotrophic bogs in Latvia. In: Mires and Peat (Eds. M. Klavins). Riga: University of Latvia Press, 2010. p. 56-70.

[19] Lishtvan, I.I., Korol, N.T. Basic Properties of Peat and Methods for Their Determination. Minsk: Nauka I Teknika, 1975. (in Russian)

[20] Tan, K. H. Soil Sampling, Preparation, and Analysis, Second Edition. New York: Taylor \& Francis group, 2005.

[21] Borgmark, A. The colour of climate: changes in peat decomposition as a proxy for climate change - a study of raised bogs in South-central Sweden. PhD thesis, Stockholm: Stockholm University, 2005.

[22] Yamaguchi, T., Hayashi, H., Yazawa, Y., Uomori, M., Yazaki, F., Bambalov, N.N. Comparison of basic characteristics of humic acids extracted from peats and other sources. International Peat Journal, 8, 1998. p. 87-94.

[23] Tombácz, E. Colloidal properties of humic acids and spontaneous changes of their colloidal state under variable solution conditions. Soil Science, 164(11), 1999. p. 814-824. http://dx.doi.org/10.1097/00010694199911000-00005

[24] Zavarzina, A.G. Demin, V.V. Nifanteva, T.I. Shkinev, V.M. Danilova, T.V., Spivakov, B.Ya. Extraction of humic acids and theit fractions in poly(ethylene glycol)-based aqueous biphasic systems. Anal.Chim.Acta, 452, 2002. p. 95-103. http://dx.doi.org/10.1016/S00032670(01)01428-3

[25] Chen, Y., Senesi N., Schnitzer, M. Information provided on humic substances by $\mathrm{E}_{4} / \mathrm{E}_{6}$ ratios. Soil Science Society of America Journal, 41, $\begin{array}{lllll}1977 . & \text { p. } & 352 & - & 358 .\end{array}$ http://dx.doi.org/10.2136/sssaj1977.03615995004100020037x

[26] Qiamg, T., Xiaoquan, S., Zheming, N. Comparative characteristic studies on soil and commercial humic acids. Fresenius Journal of Analytical Chemistry, 347. 1993. p. 330-336. http://dx.doi.org/10.1007/BF00323816
[27] Garnier-Sillam, E., Hariyento, S., Bourezgui, Y. Humic substances in peats. Analysis, 27(5), 1999. p. 405-408.

[28] Orlov, D.S. Soil humic acids and general humification theory. Moscow: MGU, 1990. (in Russian)

[29] Dick., D.P., Mangrich, A.S., Menezes, S.M.C., Pereira, B.E. Chemical and spectroscopical characterization of humic acids from two South Brazilian coals fo different ranks. J.Braz.Cham.Soc., 13(2), 2002. p. 172-182.

[30] Chin, Y.P., Aiken, G., O'Loughlin, E. Molecular weight, polydispersity, and spectroscopic properties of aquatic humic substances. Environ. Sci. Technol., $28(11), \quad 1994 . \quad$ p. $1853-1858$. http://dx.doi.org/10.1021/es00060a015

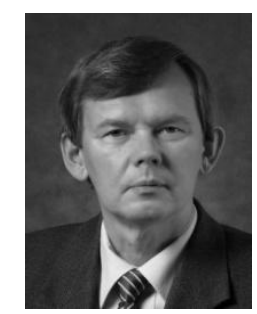

Maris Klavins, Dr. hab. chem., Professor at the University of Latvia, Faculty of Geography and Earth Sciences, Department of Environmental Sciences. M. Klavins obtained his scientific degree in chemistry of biologically active compounds at the Moscow State University in 1986 but a habilitation degree at the University of Latvia in 1994 . He is a member of the Academy of Sciences of Latvia, coordinator of International Humic Substances Research Society (IHSS). Research interests are related to studies of natural organic matter, wetlands and bogs and environmental pollution problems.

Address: University of Latvia, Raiņa bulv. 19, LV-1586, Riga, Latvia

E-mail: maris.klavins@1u.lv

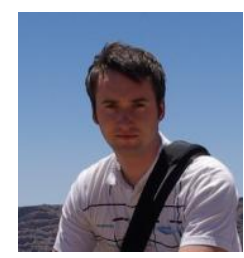

Oskars Purmalis (PhD student) received his bachelor's degree in environmental sciences from University of Latvia (Faculty of Geography and Earth sciences) in 2006 and master degree in 2008. Since the 2008 he is $\mathrm{PhD}$ Student and reseacher at the laboratory of environmental monitoring (Department of Environmental Sciences, Faculty of Geography and Earth Sciences, University of Latvia). The major interests are related to environmental chemistry, environmental proceses and nature conservation. He is a member of the International Humic Substances Society since 2006 .

Address: Raina bulv. 19, LV-1050, Riga,Latvia

E-mail: oskars.purmalis@1u.1v

\section{Māris Kḷaviṇš, Oskars Purmalis. Augsto purvu humīnskābju raksturojums}

Humusvielas ir dabiskas izcelsmes organiskās vielas ar augstu molekulmasu, heterogēnu uzbūvi un biologiski noturīgas. Tās veido augsnes, ūdeṇu un daudzu fosilo oglekli saturošo minerālu (kūdra, sapropelis, brūnogles) galveno masu uz Zemes un to īpašības variē atkarībā no izcelsmes. Humusvielas veidojas, sadaloties dzīvajai organiskajai vielai, kā arī tās degradācijas produktiem, un dzīvo organismu metabolītiem reaǵējot savā starpā un mijiedarbojoties ar vidē un dz̄ivajos organismos esošajām neorganiskajām vielām. Augstie purvi ir uzkrājuši ievērojamu apjomu organiskā oglekḷa, saglabājoties salīdzinoši nemain̄̄giem apstākḷiem, tāpēc no purviem izdalītu humīnskābju izpēte var sniegt priekšstatu par to uzbūvi, veidošanos un transformāciju. Purvos humīnskābju sastāvu ietekmē kūdras botāniskais vecums un humifikācijas procesi. Kūdras humīnskābju sastāva izpēte liecina, ka tās ir transformācijas vidū starp kūdru veidojošo veǵetāciju un oglēm. Humīnskābju veidošanās procesos vienkāršākie, nestabilākie savienojumi (ogḷhidrāti, aminoskābes u.c.) sadalās un veidojas noturīgākas struktūras aromātiskie savienojumi. Pieaugot kūdras profila dziļumam un humifikācijas pakāpei, izdalīto kūdras humīnskābju struktūrā palielinās karboksilgrupu, oglekḷa un slāpekḷa koncentrācija, bet samazinās fenolu hidroksilgrupu koncentrācija. Tas liecina par humifikācijas procesu ietekmi uz kūdras humīnskābēm un to transformāciju no kūdru veidojošajiem augiem par stabiliem aromātiskiem savienojumiem.

\section{Марис Клявиньш, Оскар Пурмалис. Характеристика гуминовых кислот верховых болот}

Гуминовые вещества (ГВ) - это природные высокомолекулярные, биологически устойчивые органические соединения с гетерогенным строением. Они образуют на Земле основную массу почв, водных органических соединений и углеродосодержащих минеральных ископаемых (торф, сапропель, бурый уголь) и их особенности варьируют в зависимости от происхождения. Гуминовые вещества образуются в процессе разложения отмерших организмов, а также продуктов метаболизма живых организмов в процессе их жизнедеятельности. При этом эти вещества взаимодействуют между между собой и с неорганическими вещестами окружающей среды, выполняя важную роль в геохимическом цикле.

В верховых болотах накоплен существенный объем органического углерода, сохраняющийся в относительно неизменных условиях. Поэтому по выделенным из торфа этих болот гуминовым кислотам можно получить представление о процессах образования, строения и трансформации ГВ. На характеристики гуминовых кислот влияют ботанический состав торфа, его возраст и физические условия процесса гумификации. В процессе образования гуминокислот простые, нестабильные соединения (углеводы, аминокислоты и др.) разделяются и образуют устойчивые структуры - ароматические соединения. С возрастанием глубины торфяного профиля и степени гумификации в гуминокислотах увеличивается карбоксильная группа, концентрации углерода и азота, в свою очередь, снижается концентрация фенольной гидроксильной группы. Это указывает о влиянии процесса гумификации на гуминокислоты торфа и их трансформацию в стабильные ароматические соединения. 